\title{
コンクリート構造物の維持管理と コンクリート診断士
}

\author{
魚 本 健 人*
}

\begin{abstract}
概 要 現在, 我が国には多数のコンクリート構造物があるが，昭和 20 年代に建設された構造物など既に 50 年以上使 用され，経年劣化している構造物も多々存在する。 21 世紀になった今日，コンクリート技術者にとってこれらのコンク リート構造物を維持管理することが最も重要な任務の一つになっている。このような状況に対処するため日本コンクリー 卜工学協会は 2001 年から「コンクリート診断士」の試験を開始する。

キーワード：劣化, 検査, 維持管理, 診断, コンクリート診断士
\end{abstract}

\section{1.はしがき}

本年から「コンクリート診断士」の講習および試験が 開始される。コンクリート診断士は今までにない新しい 資格制度ではあるが，この「コンクリート診断士」に関 しては「このような制度を作っても国家資格でないため 実務上機能しないであろう」という人もあり，「国家資 格でなくとも是非このような資格制度を利用して実務者 の技術向上をはかりたい」という人もいる。確かにこれ は国家資格ではないため，うまく機能するか否かはこれ からの社会の評価によって決定されるであろう。しかし， 21 世紀では大量の既存コンクリート樍造物を維持管理 することがコンクリート技術者の重要な任務の一つにな ることは明らかであり，そのためには十分な技術力を有 する「コンクリート診断士」が不可欠であるといえよう。

1999 年に発生した山陽新幹線のトンネルライニング からのコンクリート塊剥落事故や高架橋からのコンクリー 卜剥落, 補修後の構造物での劣化の進行と再補修などは 維持管理の大切さ，診断業務の難しさを如実に示したも のである。これらの構造物では日常点検等でコンクリー

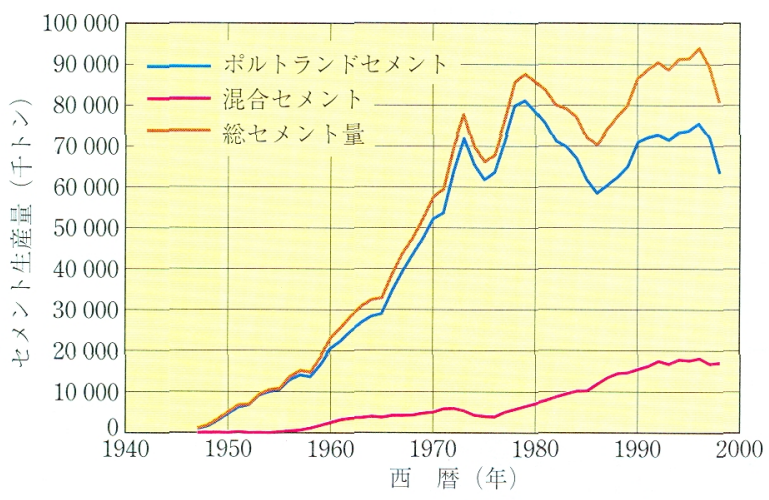

図-1＼cjkstart我が国のセメント生産量の变遷（セメント協会）

* うおもと・たけと/東京大学国際・産学共同研究センター 教授
トに種々のひび割れが認められていたが，検査員および 管理者はこの時期にコンクリートが「剥落」すると予想 できず，特別な対策を講じていなかったことからも理解 できよう。

現在，著者は日本コンクリート工学協会の「コンクリー 卜診断士講習・試験委員会」委員長を務めているが，本 文はこの委員会の委員長としてばかりでなく，コンクリー トの一研究者としてコンクリート診断の意義等も説明す る。

\section{2. 我が国の状況と劣化診断}

\section{1 現在の我が国の状況と将来予測}

現在までに我が国は大量のコンクリート構造物を建設 した。我が国から外国に輸出しているセメント量は相対 的に少ないため, 図-1に示した我が国のセメント生産 量の変遷を見ても推定することができる。1974 年まで はほぼリニアにセメント製造量が増大していることや, その後多少の変動はあるもののその伸びは緩やかになり 最近ではどちらかというとあまり增大していないことな どを見て取ることができる。このセメント生産量を基に して $1 \mathrm{~m}^{3}$ あたり $300 \mathrm{~kg}$ のセメントが使用されたと仮定 して製造されたコンクリート量を推定すると，図-2に 示すように高度成長期であった昭和 40 年（1965 年）ま

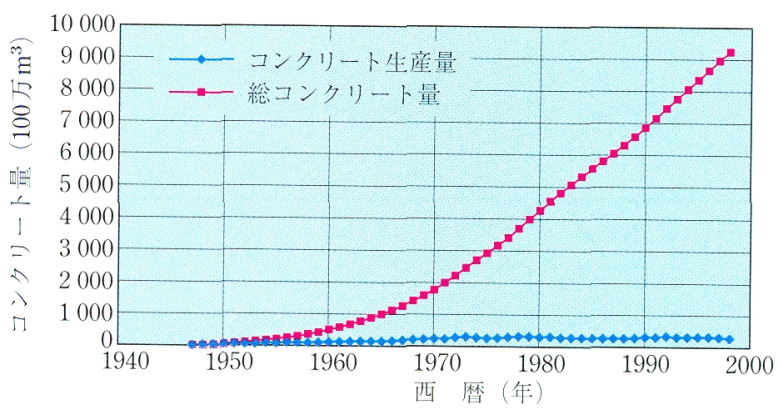

図-2 我が国のコンクリート生産量の推定値 (単年度および総生産量) 
でに生産されたコンクリートは，1998 年までのおよそ 10\% 程度にしかならない。すなわち現存しているコン クリート構造物の $90 \%$ は昭和 40 年以降に建設されたも のであるということができる。

今後の状況を予測すると, 図-3に示したように建設 後 50 年を経過した橋りょうの数と橋りょう全体の数は 2000 年以降屯増大すると予想されている。特に 2020 年 以降では，今後の新規建設の伸びにもよるが現在までと 同程度の伸びであると仮定すると, 建設後 50 年を経過 する橋りょうの割合が $50 \%$ を超える可能性がある。あ

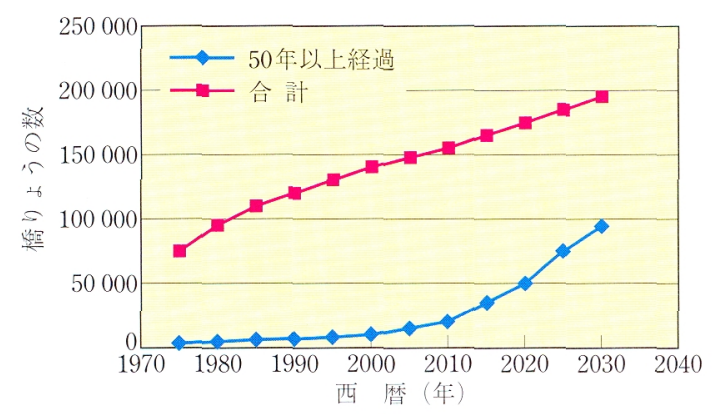

図-3 全橋りょう数と 50 年以上経過した橋りょう数の予測

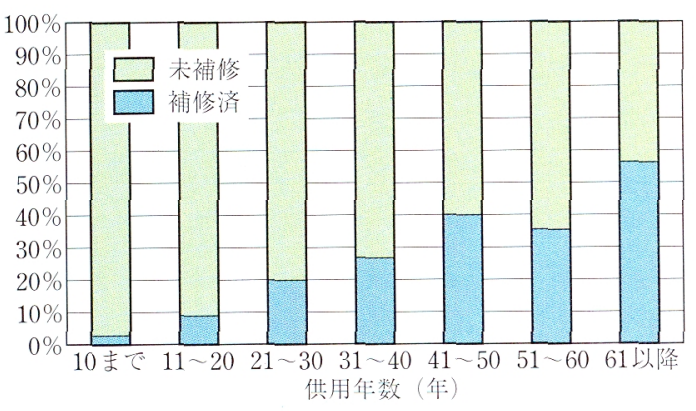

図-4＼cjkstart補修した橋りょう数割合と供用年数との関係

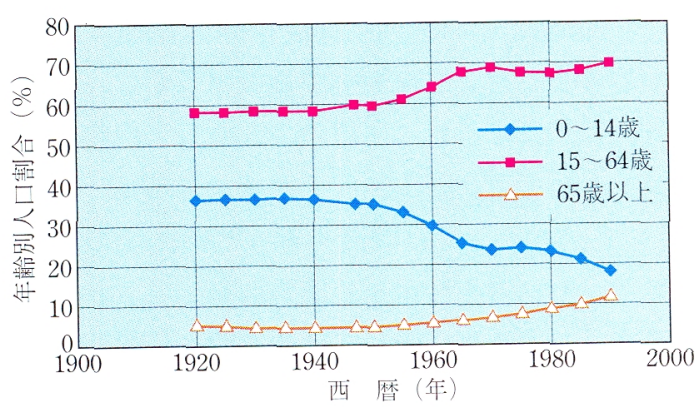

図-5＼cjkstart我が国の年齢別人口割合の変遷
し建設の伸びが減少する場合には，より大きな割合にな ることはいうまでもない。

一方，「耐久性検討委員会」で発表された資料による と, 図-4 に示すように建設後年数が経過すると補修さ れている橋りょう数の割合はほぼ直線的に増大し，50 年で約 40\%の橋りょうが補修されていることがわかる。 これらのことから明らかなように，今後は多くの構造物 を維持管理しなければならないが，補修を要する構造物 の数も急激に増大していくということができよう。

我が国の年齢分布を見ると，図-5に示したように第 2 次世界大戦後大きく変化していることが理解できる。 すなわち，0歳から14歳までの人口が著しく減少して 扔り, 逆に 65 歳以上の人口が増大している。現在では 65 歳以上の人口のほうが 14 歳以下の人口割合を上回っ ており，14歳以下の人口は1940 年頃のほぼ半数になっ ている。このことから，今後の我が国は少子高齢化が更 に進み，建設分野等の技術者も減少していくものと予想 される。

以上のことから，今後は現在より多くのコンクリート 構造物を，より少ない技術者で，あまり費用をかけずに 維持管理することが重要となり，適切な診断ならびに適 切な対処が不可欠になる上考えられる。このため，21 世紀は新規に建設すること以上に既存のコンクリート構 造物を維持管理することが重要な仕事になるが，特に各 種検査（一次検査，二次検䍒など）に基づいたコンクリー 卜構造物の検查と，各種検査結果に基づいた劣化診断が 技術者にとって非常に重要となる。

\section{2 コンクリート構造物の検査と診断}

現在実施されているコンクリート構造物の維持管理シ

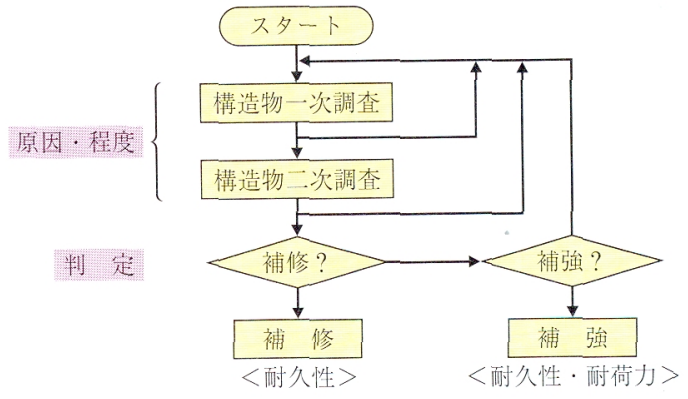

図-6 一般的なコンクリート構造物の維持管理システム

Maintenance of existing concrete structures and professional engineers for maintenance By T. Uomoto

Concrete Journal, Vol. 39, No. 4, pp. 10 13, Apr. 2001

Synopsis At present, tremendous amount of concrete structures are now being used in Japan. There are many deteriorated structures that have been in use for more than 50 years since 20's of Syowa era. One of the most important works, for the concrete engineers from the $21^{\text {st }}$ century, is to maintain these existing concrete structures. To deal with the problem, Japan Concrete Institute has started a program from this year to promote and evaluate professional engineers for maintenance.

Keywords : deterioration, inspection, maintenance, evaluation, professional engineer for maintenance 
ステムは，管理者等によって異なっているが，一般には 図-6に示したような方法が採用されている。すなわち， 定期的に目視調查等の一次検査が行われ, その結果に基 づき更に詳細な二次検査を行うか否かを決める。二次検 査では打音検査等も含めた非壊検査なども併用される が, その結果補修や補強を施すほうが良いかどうかを判 定しなければならない。更に, 補修・補強を施すのであ ればどのような補修・補強とするべきかを選定すること が求められる。これらのことからも分かるように, 判断 が必要なのは一次検査および二次検査後, その構造物に 対してどのような措置をとるかを決めるところである。

「診断」という言葉は広辞苑によると「医師が患者を 診察して病状を判断すること。転じて, 物事の欠陷の有 無を調べて判断すること」と記述されている。すなわち, 上記の維持管理システムの中で「コンクリートの各種検 査に基づき欠陥の有無を調べて， どうするべきかを判断 する」ことは「コンクリートを診断する」ことと等しい。 この判断はかなり重要で, 医師の場合と同様に, 検査の 方法やその限界を熟知し, 構造物の有している欠陥・劣 化状況などを勘案して決めることになるが，この判断が 䛊っているとさらなる劣化を引き起こし，「第三者障害」 や「事故」を起こすことになる。しかし，この診断を行 う技術者は, 従来特別な資格を有しているとはみなされ ず，それぞれの機関が有しているマニュアル（主に目視 検查の結果で判断する手法が多い）で，おおむね対処し てきたのが現状である。その結果, はしがきで述べたよ うなコンクリート剥落事故等が発生したということもで きよう。

このように重要な役割を有している「診断」を行う人 を, きちんと試験を行って資格を有しているか否かを判 定しようとする制度が「コンクリート診断士」制度であ る。なお，2.1で述べたように，これからは多数の「コ ンクリート診断士」が必要とされる状況にあること屯重 要な用件である。

\section{3. 診断士制度の概要}

\section{1 診断士制度の位置付け}

「コンクリート診断士」は日本コンクリート工学協会 の実施する講習会を受講し, さらに試験による相応のレ ベルのコンクリート診断・維持管理の知識・技術を保有 していると認定された者に与えられる名称である。しか し，これは法的に定められたものではないので，この資 格を有しない者がコンクリートの診断・維持管理の業務 を実施できないというものではない。

このコンクリート診断士に必要な知識や技術は多岐に わたっているが, 日本コンクリート工学協会の案内に例 示されているものを列記すると以下のようになる。

1）コンクリートの知識

2）鉄筋コンクリートの変状（ひび割れ, 剥離, 内部
欠陥など）

3）劣化機構（中性化, 塩害, アルカリ骨材反応, 凍 害など)

4) 測定手法

5）劣化の予測・評価

6) 判定基準

7）構造物の安全性の判定に必要な調査（部材耐力な ぞ)

8）構造物の使用性の判定に必要な調査（建築物，鉄 道, 道路, など)

9）具体的調查方法・診断方法

10）補修・補強の方法

11）技術・規準類の変遷

12）その他

これらのことからも明らかなように，コンクリートを 診断するためには非常に多くのことを知っていてなおか つそれらを活用できる能力を有することが必要である。 上記の項目のいずれを取り上げても一般のコンクリート 技術者にとってははなはだ難しく，セメントやコンクリー トに関して知っているだけでは全く不十分であるといえ よう。

\section{2 診断士制度設置までの状況}

この診断士制度が発足するまでには日本コンクリート 工学協会において平成 9 年から 2 年半の準備期間が費や されたが, 平成 11 年 10 月の理事会で承認され, 平成 13 年すなわち 21 世紀の最初の年から試験を実施するこ とに決定した。表-1に示すように, 準備委員会, 懇談 会, 委員会, 理事会などで多くの議論を重ね, 平成 11 年 4 月に正式に「コンクリート診断士講習・試験委員会」 が発足した。その後, 講習会のための「診断士講習会小 委員会」, 診断士の試験問題作成を担当する「試験問題 作成小委員会」および講習会実施を担当する「試験実施 小委員会」が設けられ, 平成 11 年 10 月に理事会で正式 に「コンクリート診断士制度」が承認された。

3.1 でも述べたように診断を行うためには非常に多く の知識と, それらを活用する能力が必要とされる。しか し, 従来, この業務に関しては断片的な情報が多く, ど のように考えるべきか等整理されていないきらいがある。 また，この分野では日々新しい技術，考え方などが導入 されるであろうと予想されることから, 最新の情報を知っ て判断することができる必要がある。そこで，本来であ れば資格の有無を判定する試験制度だけでよいことにな るが, 受験する人に最新の情報をも勉強してもらうこと を目的として「講習」を義務付けることになった。試験 で資格を取れなかった場合でもこの分野のことを理解し てもらえる技術者が増えることは，これからのコンクリー 卜構造物を維持管理する上でもプラスになると判断した といえよう。

本年は第 1 回目の講習会および試験であるため, どの 
表-1 コンクリート診断士制度審議経緯

\begin{tabular}{|c|c|c|}
\hline 年 月 日 & 委員会・理事会 & 内 \\
\hline H 9. 2.13 & 定款改定委員会技士制度部会 & 診断・補修の専門家養成の必要性を提言 \\
\hline H 9. 2.28 & 理事会 & コンクリート診断士制度検討委員会の設置を承認 \\
\hline H 9. 7. 8 & 第 1 回診断士制度検討委員会 & $\begin{array}{l}\text { 制度の規則等の検討事項について審議 } \\
\text { 委員会は, 以後継続して併 }\end{array}$ \\
\hline H10. 4.27 & 理事会 & コンクリート診断士制度検討委員会による診断士制度検討結果を答申し，実施の方針を承認した。 \\
\hline H10. 5.25 & & 建設省に診断士制度案を提出 \\
\hline H10. 8.28 & 第 1 回準備委員会 & 検討委員会は, 診断士本委員会設置のための準備委員会に名称を変更 \\
\hline H10. 10 & & 稂談会の計画・準備 \\
\hline H11. 1.13 & & 診断士制度兓談会（官庁・大学・関連団体・企業等関係者 22 名による意見交換）実施 \\
\hline H11. 4. 6 & 第 2 回準備委員会 & 愁談会意見を取り入れた修正案検討 \\
\hline H11. 4.27 & 理事会 & $\begin{array}{l}\text { コンクリート診断士制度修正 } \\
\text { コンクリート診断士講習・試験委員会設置承認 }\end{array}$ \\
\hline H11. 5.31 & $\begin{array}{l}\text { 第 } 1 \text { 回診断士 } \\
\text { 講習・試験委員会 }\end{array}$ & $\begin{array}{l}\text { 講習会・試験実施に向けて具体的活動開始 } \\
\text { 誨会馀断士テキスト作成開始 } \\
\text { 全体スケジュール設定 }\end{array}$ \\
\hline H11. 10.22 & 診断士テキスト執筆者全体会議 & $\begin{array}{l}\text { 執筆要領説明, スケジュール説明 } \\
\text { 執筆者： } 98 \text { 名 }\end{array}$ \\
\hline H11. 10.27 & 理事会 & コンクリート診断士制度を承認, 平成 13 年より実施 \\
\hline H11. 11. 12 & & プレスリリース 10 社 \\
\hline H12. 6.30 & 理事会 & $\begin{array}{l}\text { 診断士制度規則一部修正 } \\
\text { 講習会・試験開催地：東京, 大阪, 福岡とする。 } \\
\text { 診断士試験小委員会および診断士講習会小委員会設置 }\end{array}$ \\
\hline H12. 8.29 & 理事会 & $\begin{array}{l}\text { 講習会・試験実施計画を承認 } \\
\text { ・開倠期日：講習会 H 13.4, 試験 H 13.7.15 } \\
\text { •定員：講習会 } 2900 \text { 名，試験最大 } 2900 \text { 名を考慮 } \\
\text { •会場：具体的会場名 }\end{array}$ \\
\hline H12. 9. 5 & 第 6 回診断士講習・試験委員会 & $\begin{array}{l}\text { 試験実施小委員会を設置する。 } \\
\text { 講習会受講申込み受付を定員制とする。 }\end{array}$ \\
\hline H12. 9.25 & 第 1 回診断士試験小委員会 & 問題作成基本方針, 作成手順（WG 方式，スケジュール \\
\hline H12. 10.16 & 第 1 回診断士講習会小委員会 & 講習会時間割，講師選定，講演方法 \\
\hline H12. 10.16 & & $\begin{array}{l}\text { 建設省に講習会・試験実施計画書提出（報告） } \\
\text { プレス リリース 建設省記者クラブ } 45 \text { 社 } \\
\text { JCI ホームページ, 会告 } 11 \text { 月号 }\end{array}$ \\
\hline
\end{tabular}

程度の人数の人が受講・受験するか子想できないことも あり，申込み受付を定員制とし，講習会や試験の会場を 東京, 大阪, 福岡の 3 箇所に限定せざるを得なかった。 また，今年，むし予想以上の受講・受験希望者があった 場合には，次回以降講習会場を増やすなどの対策を講じ ることになろう。

\section{4. あとがき}

既存のコンクリート構造物を維持管理していくことは 21 世紀のコンクリート技術者としてはなはだ重要であ
る。どの程度の技術者に関心があるのかは不明であるが, かなり重要な技術であることはいうまでもない。従来, 維持管理に携わっている技術者の評価は, 新規構造物を 建設する技術者に比較してあまり高くなかったが，この 「コンクリート診断士」制度がこれらの技術者の評価を 高める上で役に立つのであれば幸いであると考えている。 是非多くの方々に診断の重要性を認識していただいて, 「コンクリート診断士」の資格を取得していただきたい と考えている。 